\section{Nok epidemiologi for klinikere?}

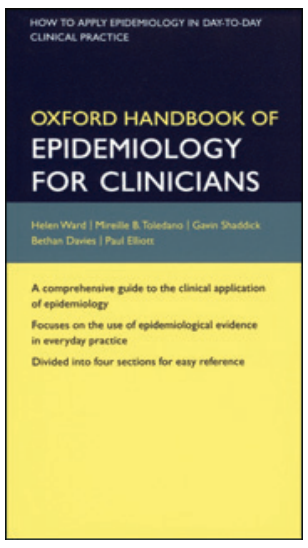

Helen Ward, Mireille B. Toledano,

Gavin Shaddick et al.

Oxford handbook of epidemiology for clinicians

388 s, tab, ill. Oxford: Oxford University Press, 2012. Pris GBP 28

ISBN 978-0-19-852988-0

I serien med håndbøker fra Oxford University Press har det nå også kommet en i epidemiologi. Målet er å gi klinikere og medisinstudenter basal kunnskap i dette metodefaget. Søkelyset er rettet mot hvordan kunnskap basert på epidemiologisk forskning kan brukes i det kliniske arbeidet.

Boken er delt inn i fire deler der forfatterne i den første delen tar for seg bruken av epidemiologi i møte med den enkelte pasient, nærmere bestemt klinisk beslutningslære og hvordan sykdomsrisiko kan kommuniseres med pasienten. I andre del om evidensbasert klinisk praksis beskriver forfatterne blant annet litteraturs $\varnothing \mathrm{k}$, kritisk lesing av epidemiologiske artikler, prinsipper for screening og forebyggende medisin og gjennomføring av kvalitetssikringsstudier. Del tre handler om epidemiologiske metoder. Forfatterne gir her leseren en innføring i hvilke typer epidemiologiske studier det er vanlig å regne med, deres bruk, styrker og svakheter. Deretter følger en innføring i basale statistiske begreper og de vanligste statistiske metodene i epidemiologien. Det finnes for øvrig en egen håndbok i medisinsk statistikk i den samme bokserien. Fjerde del er en kortfattet oversikt over deskriptiv epidemiologi, risikofaktorer og preventive tiltak ved en rekke vanlige sykdommer.

Boken er i lommeformat. Det er hendig, skjønt de færreste klinikere vil vel prioritere å gå med en epidemiologibok i frakkelommen? Teksten er konsis og oversiktlig, og utstrakt bruk av underoverskrifter og punktvis presentasjon av stoffet gjør det lett å finne frem. Blant annet er kapitlene om ulike studiedesign og statistiske metoder belyst med gode eksempler.

Et imponerende bredt spekter av epidemiologien har fătt plass i denne håndboken. Det betyr samtidig at informasjonen om hvert enkelt tema blir kortfattet og noen ganger for enkel og unyansert. Boken kan derfor ikke erstatte grunnleggende lærebøker i epidemiologi, og den gir heller ikke nok detaljkunnskap for dem som vil gå inn i epidemiologisk forskning. Men den gir derimot oversiktlig informasjon, og den som trenger hjelp til å forstå og bruke epidemiologisk kunnskap i den kliniske hverdagen, vil finne mange gode svar.

\section{Bjørn Olav Åsvold}

Det medisinske fakultet

Norges teknisk-naturvitenskapelige universitet

\section{Et raskt blikk på folkehelse og epidemiologi}

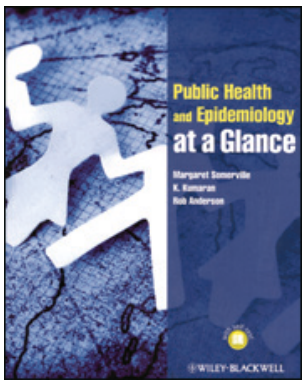

Margaret Somerville, K. Kumaran,

Rob Anderson

Public health and epidemiology at a glance

94 s, tab, ill. Chichester: Wiley-Blackwell,

2012. Pris GBP 25

ISBN 978-0-470-65445-3

Public health and epidemiology at a glance er en kortfattet lærebok som retter seg mot studenter og yngre leger. Hensikten er å gi en introduksjon til et komplekst tema på en klar og konsis måte. Boken inngår i en serie på nærmere 30 titler fra det samme forlaget. Dette er en nykommer i motsetning til enkelte andre som tidligere har kommet i flere opplag.

Det er fem deler: epidemiologi og evidensbasert medisin, hvordan måle helse i populasjonen, forbedre og beskytte helse, helseøkonomi og effektivt helsevesen. Alle kapitlene består av to sider med en side illustrasjon og en side tekst. På slutten er det oppgaver med fasit for å sjekke om leseren har forstått det vesentlige i teksten. I tillegg er det et vedlegg som omhandler praktiske forhold angående gjennomføringen av epidemiologiske studier, og en side med artikler som tips til videre lesning. Boken er på kun 94 sider. Den er meget overkommelig og bidrar ikke negativt til den omfattende mengden lesestoff man skal komme seg gjennom i løpet av studiet.

Illustrasjonene kan av og til ha veldig liten skrift, noe som ødelegger inntrykket. Helsideformatet er kanskje heller ikke helt vellykket, men det deler denne boken med alle andre i serien. En annen sak er at hvis du jobber innenfor folkehelse og epidemiologi, går ikke denne teksten dypt nok til å være verdt lesningen. Kapitlene som omhandler sosiale ulikheter og helse, fenger spesielt og er et viktig tema for de som praktiserer medisin.

I et medisinstudium med mye klinisk praksis på sykehus får de kliniske fagene stor plass. Det er veldig lett at emnene som forfatterne her tar for seg, blir nedprioritert - litt fordi stoffet er annerledes og litt fordi de bøkene som er tilgjengelige, kan virke for omfattende. Derfor vil jeg anbefale denne boken fordi den er lettlest og gir et grunnlag for å forstå mer, samtidig som den øker lysten til å lese mer. Den beveger seg hele tiden på overflaten, men kanskje er hele poenget at vi som studenter først må få lyst til å lære mer om epidemiologi, folkehelse og samfunnsmedisin, og der treffer boken godt.

Ane-Kristine Finbråten

Institutt for laboratoriemedisin, barne- og kvinnesykdommer Norges teknisk-naturvitenskapelige universitet 